\title{
Kenaf Fiber Composite in Automotive Industry: An Overview
}

\author{
F. Hassan" ${ }^{\#}$ R. Zulkifli ${ }^{*}$ M. J. Ghazali ${ }^{*}$, C. H. Azhari* \\ *Department of Mechanical and Materials Engineering, Faculty of Engineering and Built Environment, Universiti Kebangsaan Malaysia, \\ 43600 Bangi, Selangor, Malaysia \\ E-mail:farafahas@gmail.com,rozli@eng.ukm.my.my,mariyam@vlsi.eng.ukm.my,husna.azhari@ukm.edu.my
}

\begin{abstract}
Recently, natural fibers become attractive to automotive industry as an alternative reinforcement for glass fiber reinforced thermoplastics. Additionally, natural fiber components in the automotive industry can provide numerous advantages compared to synthetic conventional such as reduction of weight and cost, recyclability, renewability and in addition to eco-efficiency. Thus, the use of natural fibers in the automotive industry has shown increasingly stringent environmental criteria. Furthermore, amongst grouped bast fibers such as flax, hemp, jute, ramie, and kenaf; kenaf fiber is seen as a potential natural fiber with robust mechanical properties. Kenaf fiber had been explored to enhance desired mechanical properties as automotive structural components. As usual, natural fibres have some issues and disadvantages when used as reinforcements for polymeric composites. Therefore, some modification performed on fibers such as chemical treatment was carried out. In addition, the use of a coupling agent and a plasticizer can also increase fiber-matrix adhesive bonding.
\end{abstract}

Keywords — automotive; natural fibre; kenaf fibre; composite

\section{INTRODUCTION}

Automotive production rate has increased and estimated to reach 76 million cars annually by 2020 . For that reason, utilization of bio-composite will be major leads to decrease in weight of vehicles and emissions. And yet, it is estimated that a $25 \%$ reduction in car weight would be equivalent to saving 250 million barrels of crude oil [1]. Due to its relevance, the automotive industry transforming the challenges [2] by improving recyclability of newly produced [3] and producing a bio-based product that allows domestic natural resources especially for the body of the cars so that weight reduction can be achieved [4]. For instance, natural fiber composites with thermoplastic and thermoset matrices have been embraced by European car manufacturers and suppliers for door panels, seat backs, headliners, package trays, dashboards and interior parts [5]. Natural fibers reinforced composites are primarily used as low-cost materials that have been used in applications such as automotive interior linings [6].

Natural fibers have gained renewed interest, especially as a glass fiber substitute in automotive industries [7]. Generally, natural fiber could be classified into animal, plant and mineral sources. Among the three types of classification, the natural plant fiber has more potential. According to the plant category, the fibers are extracted such as bast, leaf, seed, wood, fruit and straw (refer Fig. 1). And among that, bast fibers have low density and higher mechanical properties, hence the possibility to reinforcements in lightweight composite for automotive parts [8].

As seen in Fig. 1, bast fibers derived from flax, hemp, jute, ramie and kenaf. Those are providing automobile part reinforcement due to such drivers as reductions in weight, cost and $\mathrm{CO}_{2}$ yet as a "green" or ecofriendly [5]. When an eco-design is considered, information on environmental with mechanical behaviour is increasingly being requested too. A significant recent development in this area has been the appearance of bio composites (biopolymers reinforced by plant fibres), which combine good mechanical performance and low environmental impacts [9]. Due to consideration of environmentally friendly material, natural fibre reinforced polymer composites have raised up a great attentions and interests among materials scientists and engineers for their mechanical properties and potential contribution [10]. They are renewable, cheap, completely or partially recyclable and biodegradable. They are high specific strength and modulus materials, low prices, recyclable, easily available in some countries [11].

Currently, natural fibre as composites have two issues that need to be addressed a) resin compatibility, b) water absorption [12]. And for that reason, demand use of physical and chemical treatments/compatibilizer to enhance the adhesion between fibre and matrix [13]. 


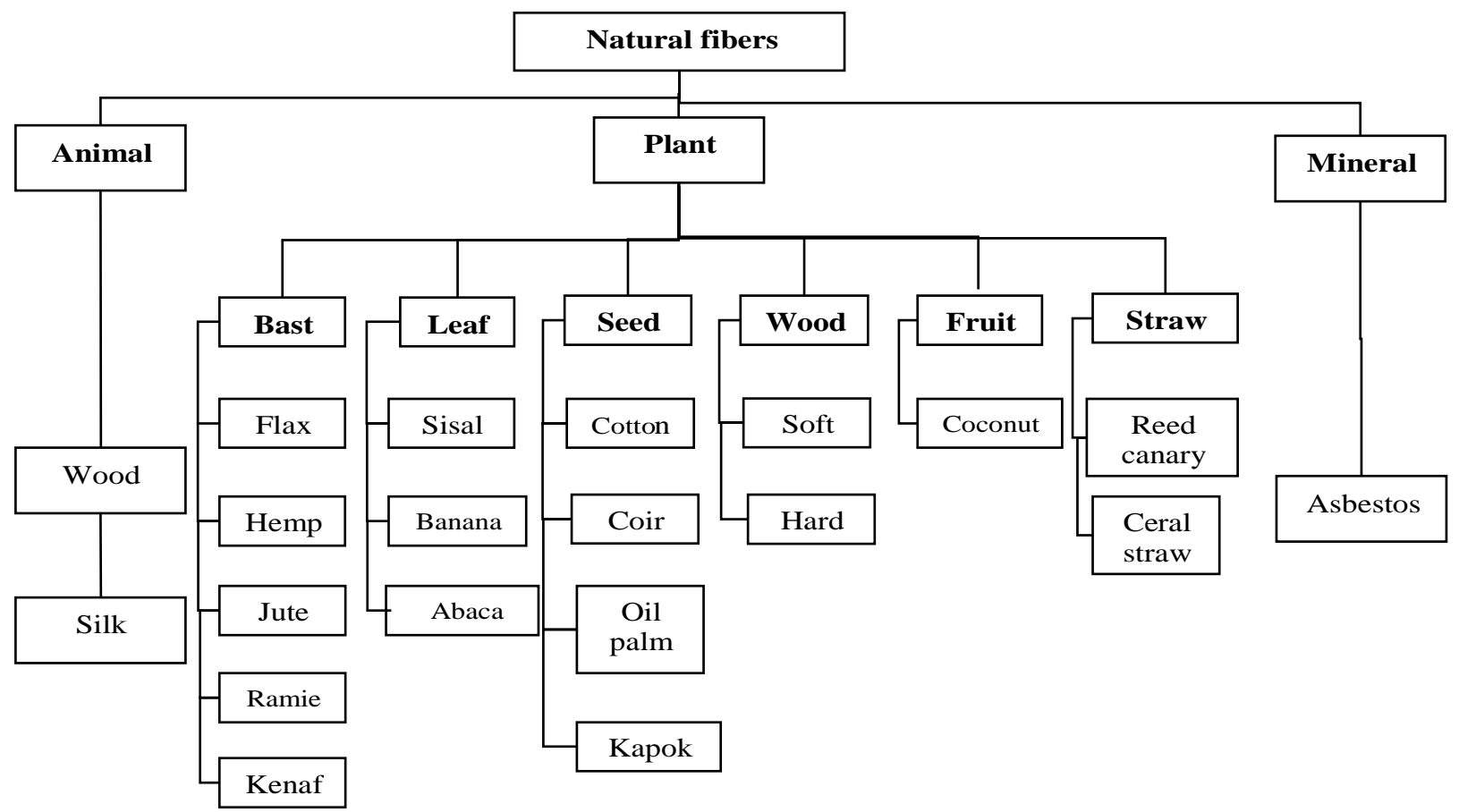

Fig 1. Classification of natural fibers [7]

Natural fibres is the hydrophilic nature of the natural fibres which may lead a fibre degradation [14]. Due to fibre degradation problems like the adhesion or interfacial bonding, treatment and coupling agents could be considered and for the improvement of the properties. The modification of fibres generally involves surface treatment of fibre is designed to facilitate a better adhesion between the fibre and the matrix. The surface treatment can be accompanied by either adding compatibilizers or by chemically treating the fibre. Effective surface treatments not only remove native surface materials and leave behind more active functional groups to promote wetting, but also roughen the surface to some degree, therefore increasing surface area and potentially enhancing mechanical interlocking [15].

Three types of chemical treatments are bleaching, acetylation, and alkali treatment aim to improve the fibre/matrix adhesion by increasing the surface roughness of the natural fibres through of clean the fibre surface from impurities and disrupting the moisture absorption process through of coat of $\mathrm{OH}$ groups in fibre [16]. Fibre modification through the alkalisation process can reduce the moisture absorption.

Besides, coupling agents build up chemical and hydrogen bonds which reduce fibre/matrix debonding caused by moisture thus improving the fibre/matrix adhesion and consequently. The manner in which composite materials absorb water depends upon several factors such as temperature, fibre volume fraction, the orientation of reinforcement, permeability nature of fibre, the area of exposed surfaces, diffusivity, the reaction between water and matrix and surface protection [10]. Silane treatment is used to stabilise polymer composites reinforced with natural fibres by treating the fibres to resist against water leaching.

\section{MAterial AND METHOD}

Natural fibre represents an opportunity to partially the environmental impacts by integrating biodegradable filler material [17]. And classified natural fibres into 6 types as follows: bast fibres (flax, hemp, jute, ramie and kenaf) [10], leaf fibres (sisal, banana, abaca), seed fibres (cotton, coir, oil palm and kapok), core fibres (kenaf, hemp and jute), grass and reed fibres (wheat, corn and rice) and all other types (wood and roots) [18]. Amongst them, kenaf (Hibiscus cannabinus L. family Malvacea) is one of the strong and stiff agro based fibres and has sufficient potential to reinforce polymers.

Kenaf fibre consists of main cellulose $(45-57 \%)$ as well as hemicelluloses $(21.5 \%)$, lignin (8-13 wt\%), pectin (3-5 wt\%) and waxy substances [19], [4]. Kenaf is a new type of economic crop which currently being grown in Mississippi, Texas, Florida, Arizona and North Carolina. Its excellent fiber strength, kenaf fiber has great potential for use in industrial nonwoven materials and for competing with flax and hemp fibers on the global market [3]. Fig. 2 showed the parts of kenaf stem (core, bast and innerbast). The kenaf bast fiber is known to have the potential as a reinforcing fiber in thermoplastic composites because of its superior toughness and high aspect ratio in comparison to other fibre [19].

The sustainable properties of kenaf include [19], [22]:

- Kenaf plant absorbs carbon dioxide from the air at a significantly high rate

- Kenaf plant absorbs nitrogen and phosphorous from the soil

- It is easily recycled

Due to the light weight of kenaf fiber composites, the fuel consumption and emission are improved especially in automotive industries. 

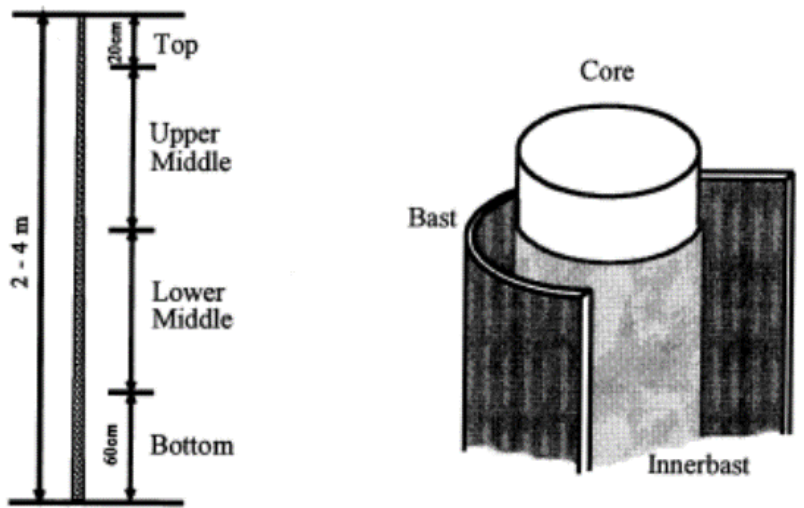

Fig. 2 Sampling positions and parts of kenaf stems [20], [21]

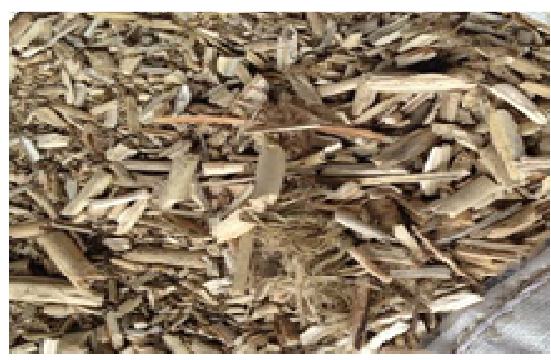

(a)

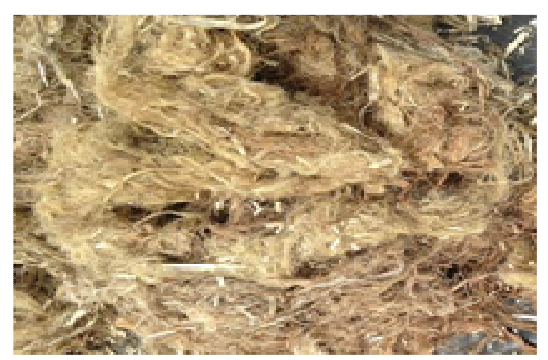

(b)

Fig. 3 (a) Kenaf core (b) Kenaf bast

TABLE I

FIBRE DIMENSIONS OF KENAF FIBRE

\begin{tabular}{|l|l|l|l|l|}
\hline Kenaf Fibre & Length $(\mathbf{m m})$ & Diameter $(\boldsymbol{\mu m})$ & Lumen Diameter $(\boldsymbol{\mu m})$ & Cell Wall Thickness $(\boldsymbol{\mu m})$ \\
\hline Bast fibre & 2.32 & $21.9 \pm 4.6$ & $11.9 \pm 3.4$ & $4.2 \pm 0.8$ \\
\hline Core fibre & 0.74 & $22.2 \pm 4.5$ & $13.2 \pm 3.6$ & $4.3 \pm 0.7$ \\
\hline
\end{tabular}

Table 1 showed the dimension of kenaf fiber for the outer part (bast fiber) and an inner part (core fiber). Both parts showed good mechanical properties even with a different dimension. Comparing with other types of plant fiber, kenaf fiber becomes more potential because of both part of kenaf; bast and core give a good mechanical performance. Different with certain fiber, only the outer part give a good performance and some fibers only the inner part that can be used. Considering this advantages, kenaf tends to be growth as another potential natural fiber that can be substitute glass fiber in the automotive industry.

TABLE III

COMPARISON PROPERTIES KENAF AND GLASS FIBER [4]

\begin{tabular}{|l|l|l|}
\hline Properties & Kenaf Fiber & Glass Fiber \\
\hline Density & 1.4 & 2.5 \\
\hline Strength & $284-800$ & $2000-3000$ \\
\hline Modulus $(\mathrm{GPa})$ & $21-60$ & 70 \\
\hline Elongation at break & 1.6 & 2.5 \\
\hline
\end{tabular}

Table 2 showed the comparative properties of density, strength, modulus and elongation at break between kenaf fiber and glass fiber. Despite this, glass fiber showed a dominant value for each property yet extensively applied in the automotive component. Apparently, kenaf fiber has some advantages over glass fiber in terms of cost, density, renewability, abrasiveness biodegradability. To enhance the properties of composites, it depends on fiber matrix interface, and this contributes to transfer stress from the matrix to the fiber.

\section{RESULTS AND DISCUSSION}

The automotive industry uses of natural fiber reinforcement, which proven that viable in a number of automotive parts. Currently, flax, sisal, and hemp are processed into door cladding, seatback linings and floor panels [5] (refer Fig. 5). Prior to this, proper material selection of natural fibers and careful design should be count into in order to achieve good impact behavior especially the main structure like bumper beam for absorbing the energy of collisions [4].

Several well-known compositions of kenaf fiber with matrix and some additive can meet the automotive requirement for interior and exterior parts as long as nonstructural and semi-structural applications. Refer Table 4, twisted kenaf fiber [4] showed the performance of beams increased with hybrid kenaf/glass reinforced material. This proved that it could be utilized in automotive structural components. A twisted kenaf hybrid material could be improved by optimizing the structural parameters such as thickness, beam curvature and strengthening ribs. The application in automotive parts as bumper beams and front end modules. 


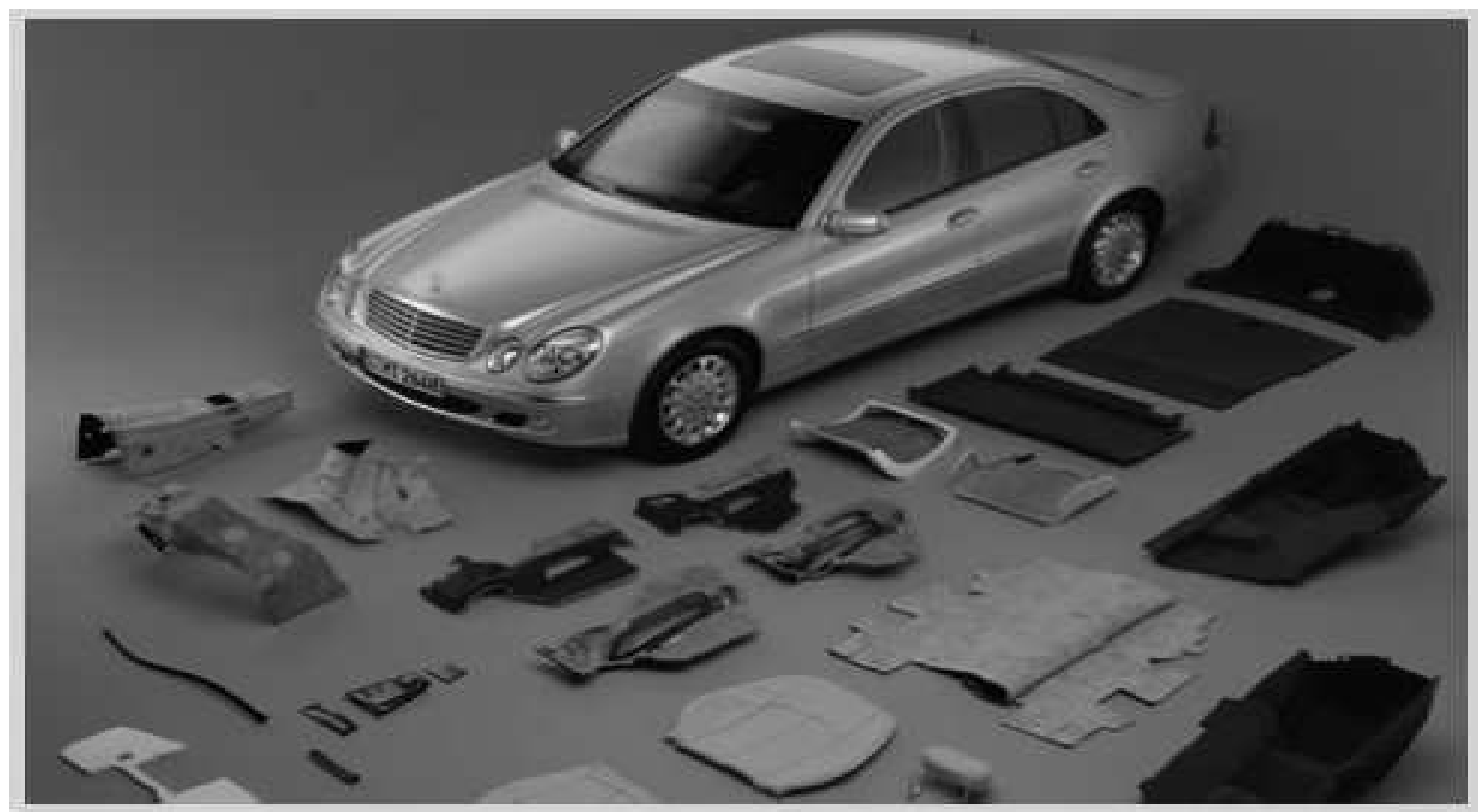

Fig. 4 Flax, hemp, sisal, wool and other natural fibers are used to make 50 Mercedes-Benz E-Class components [5]

TABLE IIIII

TYPES OF FIBER AND CURRENT APPLICATION [5]

\begin{tabular}{|l|l|}
\hline Types of Fiber & Application \\
\hline Coconut fiber & Seat bottoms, back cushions and head restraints \\
\hline Cotton & Sound proofing \\
\hline Wood fiber & Seatback cushion, sliding door inserts for the Ford Freestar \\
\hline Abaca & Underfloor body panels \\
\hline Kenaf and flax mixture & Package trays and door panel inserts for Saturn L300s European-market Opel Vectras \\
\hline Wood fiber & Seatbacks for the Cadillac DeVille and in the cargo area floor of the GMC Envoy and Chevrolet TrailBlazer \\
\hline Corn & Ford mounts Goodyear tires \\
\hline Kenaf & Lexus package shelves \\
\hline
\end{tabular}
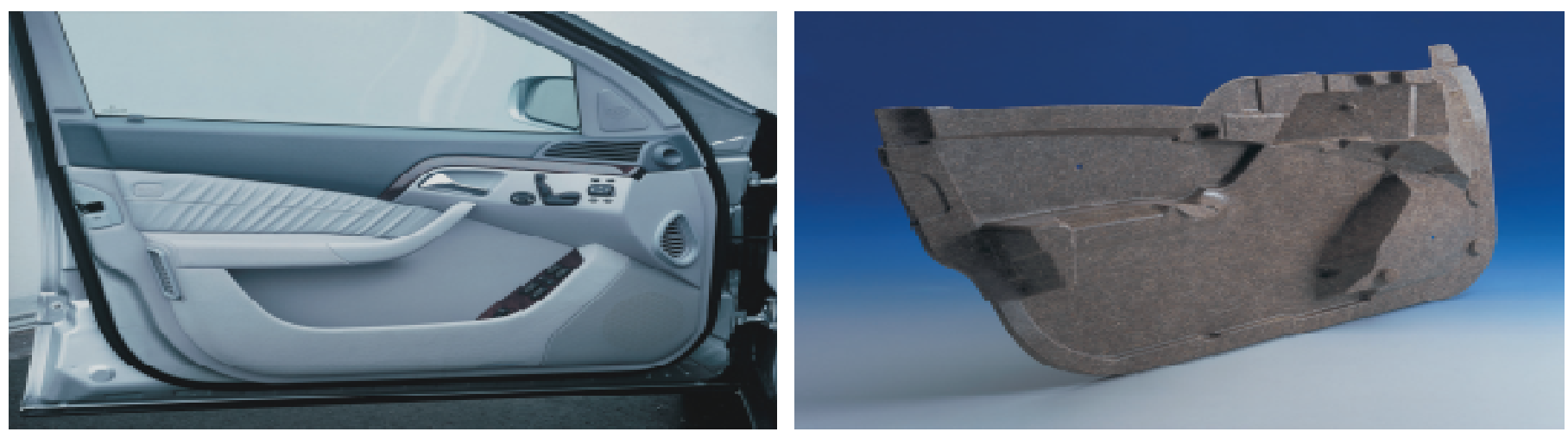

Fig. 5 Modern door inner trim panels are molded using mats of 60\% natural fiber in a Baypreg® polyurethane resin (Courtesy of Bayer Polymers) [23]

TABLE IVV

KENAF FIBER COMPOSITION

\begin{tabular}{|l|l|}
\hline Composition & Findings \\
\hline Twisted kenaf fiber LFRT (TKLFRT) and LFRT & Performance of beams increased \\
\hline Kenaf with PFA poly(furfuryl alcohol) bio-resin & Good damping behavior \\
\hline $\begin{array}{l}\text { Kenaf and ramie fiber nonwovens. With binder: PVA and Acrylic } \\
\text { copolymer }\end{array}$ & $\begin{array}{l}\text { Enhance the performance composite thermal and mechanical } \\
\text { properties }\end{array}$ \\
\hline Kenaf with PLA & Good aesthetics and strength \\
\hline
\end{tabular}


The composite of bast kenaf with PFA poly(furfuryl alcohol) bio-resin [24] possess good damping behavior as shown by the DMA analysis [28], which shows the ability of the green composites to use in automotive industry. This ability proved that natural fiber been utilized in the automotive industry.

There is not only kenaf with the matrix, but there's also a nonwoven kenaf and ramie fiber been utilize with a binder so-called PVA and the acrylic copolymer [19]. This composition had been enhancing the performance and the composite thermal-mechanical properties. Acrylic copolymer binder well-known be able to cross-link at high temperatures. Besides that, from the padding times, it showed significantly influenced the tensile properties of the acrylic-copolymer bonded composite. The example in the automotive interior or exterior application is a headliner.

Another lightweight application in the automotive industry by kenaf which is the matrix with PLA [25]. Biopolymer PLA provides good aesthetics and strength and easy process ability in most equipment. PLA is brittle, and it needs modification to improve the mechanical and thermal properties to achieve a better adhesion between the fiber and the matrix. It was found that standard PLA resins are suitable for the manufacture of kenaf fiber reinforced laminated bio-composites with useful engineering properties.

TABLE V

PROPERTIES OF TyPICAL THERMOSET POLYMERS FOR NATURAL FiBER COMPOSITES [7]

\begin{tabular}{|c|c|c|c|}
\hline Property & Polyester Resin & Vinylester Resin & Epoxy \\
\hline Density $(\mathrm{g} / \mathrm{cc})$ & $1.2-1.5$ & $1.2-1.4$ & $1.1-1.4$ \\
\hline Elastic Modulus (GPa) & $2-4.5$ & $3.1-3.8$ & $3-6$ \\
\hline Tensile Strength (MPa) & $40-90$ & $69-83$ & $35-100$ \\
\hline Compressive Strength (MPa) & $90-250$ & 100 & $100-200$ \\
\hline Elongation $(\%)$ & 2 & $4-7$ & $1-6$ \\
\hline Cure Shrinkage $(\%)$ & $4-8$ & - & $1-2$ \\
\hline Water Absorption $\left(24 \mathrm{~h} @ 20^{\circ} \mathrm{C}\right)$ & $0.1-0.3$ & 0.1 & $0.1-0.4$ \\
\hline Izod Impact, Notched $(\mathrm{J} / \mathrm{cm})$ & $0.15-3.2$ & 2.5 & 0.3 \\
\hline
\end{tabular}

TABLE VI

PROPERTIES OF TYPICAL THERMOPLASTIC POLYMERS USED IN NATURAL FIBER COMPOSITE FABRICATION*

\begin{tabular}{|l|l|l|l|l|l|l|}
\hline Property & PP & LDPE & HDPE & PS & Nylon 6 & Nylon 6,6 \\
\hline Density (g/cm3) & $0.899-0.920$ & $0.910-0.925$ & $0.94-0.96$ & $1.04-1.06$ & $1.12-1.14$ & $1.13-1.15$ \\
\hline Water Absorption -24 hours (\%) & $0.01-0.02$ & $<0.015$ & $0.01-0.2$ & $0.03-0.10$ & $1.3-1.8$ & $1.0-1.6$ \\
\hline $\mathrm{Tg}\left({ }^{\circ} \mathrm{C}\right)$ & -10 to -23 & -125 & -133 to -100 & - & 48 & 80 \\
\hline $\mathrm{Tm}\left({ }^{\circ} \mathrm{C}\right)$ & $160-176$ & $105-116$ & $120-140$ & $110-135$ & 215 & $250-269$ \\
\hline Heat Deflectionm Temp $\left({ }^{\circ} \mathrm{C}\right)$ & $50-63$ & $32-50$ & $43-60$ & Max. 220 & $56-80$ & $75-90$ \\
\hline $\begin{array}{l}\text { Coefficient of Thermal Expansion } \\
\left(\mathrm{mm} / \mathrm{mm} /{ }^{\circ} \mathrm{C} \times 105\right)\end{array}$ & $6.8-13.5$ & 10 & $12-13$ & $6-8$ & $8-8.6$ & $7.2-9$ \\
\hline Tensile Strength $(\mathrm{MPa})$ & $26-41.4$ & $40-78$ & $14.5-38$ & $25-69$ & $43-79$ & $12.4-94$ \\
\hline Elastic Modulus $(\mathrm{GPa})$ & $0.95-1.77$ & $0.055-0.38$ & $0.4-1.5$ & $4-5$ & 2.9 & $2.5-3.9$ \\
\hline Elongation $(\%)$ & $15-700$ & $90-800$ & $2.0-130$ & $1-2.5$ & $20-150$ & $35->300$ \\
\hline Izod Impact Strength $(\mathrm{J} / \mathrm{m})$ & $21.4-267$ & $>854$ & $26.7-1,068$ & 1.1 & $42.7-160$ & $16-654$ \\
\hline
\end{tabular}

*Selected data obtained from [26]; LDPE = low-density polyethylene; HDPE = high-density polyethylene; PP = polypropylene; PS = polystyrene

There are two types of blending with natural fiber composite matrix that been used to enhance the properties of the fiber. Refer to Table 5 and 6, thermoset matrix been used has a good mechanical performance. Contrast to the thermoplastic matrix showed advantages in weight reduction and importantly recyclability. Both matrices have pros and cons depends on application requirement because each natural fiber has different properties. Hence, the different fibers need different blending type to achieve the needed properties. For example, to fullfill automotive application that needs higher tensile strength so we should blend fiber with thermoset matrix because it performs high tensile strength rather than a thermoplastic matrix. But, it showed a contrast izod impact strength between thermoset and thermoplastic matrix.

Fig. 6 shows natural fiber mat that been processed into a door inner panel blending with thermoplastic matrix (PP). The composition of the part consist of material specifics:
$1,600 \mathrm{~g} / \mathrm{m} 2,50 \%$ kenaf and blend with $50 \%$ polypropylene. The mats are heated to melt the thermoplastic fibres and pressed into the desired shape in a cold press, and the parts are sensitive to temperature. Alternatively, non-wovens based on natural fibres are coated with thermosets such as epoxy or polyurethane resins is generated by curing the resin under heat in a hot press (Fig. 7). The mats have to be moulded immediately after impregnation because of the high reactivity of the thermoset.

\section{CONCLUSION}

In conclusion, annual production of the automotive industry will increase constantly. Therefore, apparently, there is a critical issue for our next decade with the biodegradable or recyclability materials. For that reason, the automotive industry is growing rapidly due to natural fiber reinforced composites. Compared to natural fiber, glass fiber had good performance in terms of physical and mechanical 
properties but the low cost, processing advantages and low density becoming as a value added to the natural fiber's performance for automotive parts. Over glass fiber, natural fiber consuming less energy during the natural fiber manufacture and had been potential in lower mass structures. The availability of natural fibers like kenaf have some advantages over traditional reinforcement materials such as glass fiber and have a potential to meet requirement new automobile design. In order to fulfill application in automotive structures [27], a few modification in design, fiber treatment, the use of the additive, material selection and method for production are necessary.

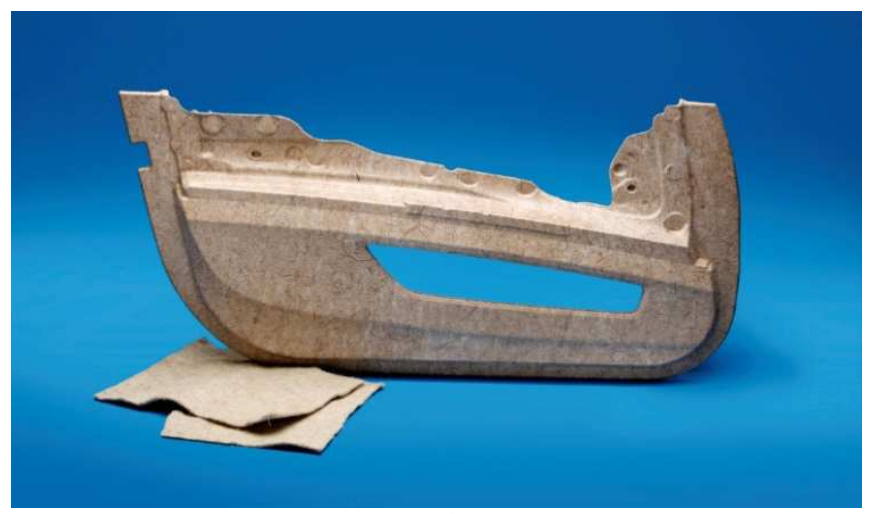

(b)

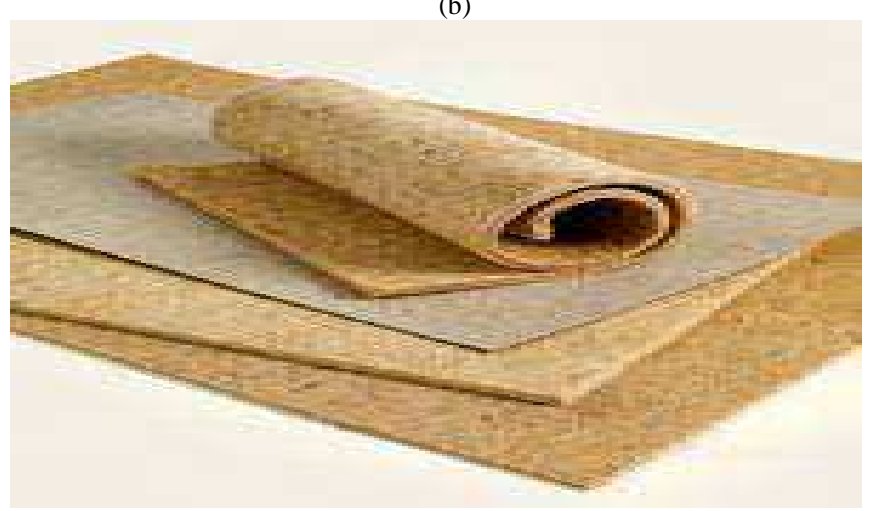

(a)

Fig. 6 (a) Natural fiber mat (b) Door inner panel

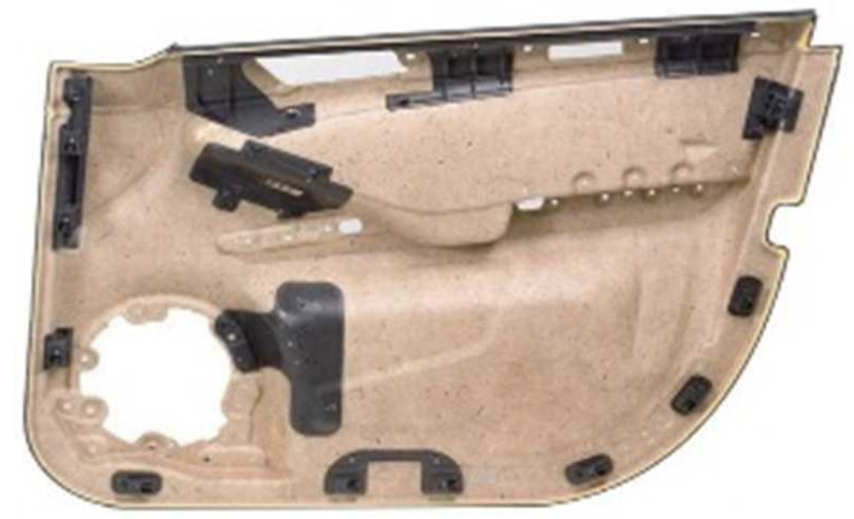

Fig. 7 Heated and molded mat into door panel

\section{REFERENCES}

[1] R. Ranjan, P. K. Bajpai, and R. K. Tyagi, "Mechanical characterization of banana/sisal fibre reinforced PLA hybrid composites for structural application," Engineering International, vol. 1, pp. 38-49, Jun. 2013.
[2] C. A. D. Silva, "Sustainable design of automotive components throuah jute fiber composites," Phd thesis, Technical University of Lisbon, Portugal, 2010.

[3] Y. Chen, L. Sun, O. Chiparus, I. Negulescu, V. Yachmenev, and M. Warnock, "Kenaf/ramie composite for automotive headliner," Journal of Polymers and the Environment, vol. 13, pp. 107-114, Apr. 2005.

[4] J. Jeyanthi, S. Jeevamalar, and J. Jancirani, "Influence of natural fibers in recycling of thermoplastics for automotive components," in Proc. IEEE ICAESM'12, 2012, p. 211.

[5] J. Holbery and D. Houston, "Natural-fiber-reinforced polymer composites in automotive applications," JOM, vol. 58, pp. 80-86, Nov. 2006.

[6] V. Fiore, G. Di Bella, and A. Valenza, "The effect of alkaline treatment on mechanical properties of kenaf fibers and their epoxy composites," Composites Part B: Engineering, vol. 68, pp. 14-21, Jan. 2015.

[7] A. K. Mohanty, M. Misra, L. T. Drzal, S. E. Selke, B. Harte, and G. Hinrichsen, Natural Fibres, Biopolymers and Biocomposites, 1st ed., Florida, USA: CRC Press, 2005.

[8] M. S. Salit, Research on Natural Fibre Reinforced Polymer Composites, Selangor, Malaysia: Universiti Putra Malaysia Press, 2009.

[9] A. Le Duigou, C. Baley, Y. Grohens, P. Davies, J. Y. Cognard, R. Créach'cadec, and L. Sohier, "A multi-scale study of the interface between natural fibres and a biopolymer," Composites Part A: Applied Science and Manufacturing, vol. 65, pp. 161-168, Oct. 2014.

[10] Z. N. Azwa, B. F. Yousif, A. C. Manalo, and W. Karunasena, "A review on the degradability of polymeric composites based on natural fibres," Materials and Design, vol. 47, pp. 424-442, May 2013.

[11] M. Azlan and N. V. David, "Biodegradable material options for industrial and goods packaging," in Proc. IEEE CHUSER'11, 2011 p. 23.

[12] M. P. Westman, L. S. Fified, K. L. Simmon, S. G. Laddha, and T. A Kafentzis. (2010) Natural fiber composites: A review. [Online]. Available:

http://s3.amazonaws.com/academia.edu.documents/45693682/Lit_re view.pdf?AWSAccessKeyId=AKIAJ56TQJRTWSMTNPEA\&Expir es $=1480747664 \&$ Signature $=$ BtpNyPoNWn09bz9\%2Fl2tEuSPiPJw $\%$ 3D\&response-content-

disposition=inline $\% 3 \mathrm{~B} \% 20$ filename\%3DPNNL19220_Natural_Fiber_Composites_A_Re.pdf.

[13] H. Deka, M. Misra, and A. Mohanty, "Renewable resource based 'al green composites' from kenaf biofiber and poly(furfuryl alcohol) bioresin," Industrial Crops and Products, vol. 41, pp. 94-101, Jan. 2013.

[14] M. Zampaloni, F. Pourboghrat, S. A. Yankovich, B. N. Rodgers, J. Moore, L. T. Drzal, A. K. Mohanty, and M. Misra, "Kenaf natural fiber reinforced polypropylene composites: A discussion on manufacturing problems and solutions," Composites Part A: Applied Science and Manufacturing, vol. 38, pp. 1569-1580, Jun. 2007.

[15] A. A. Mamun, H. P. Heim, D. H. Beg, T. S. Kim, and S. H. Ahmad, "PLA and PP composites with enzyme modified oil palm fibre: A comparative study," Composites Part A: Applied Science and Manufacturing, vol. 53, pp. 160-167, Oct. 2013.

[16] T. Alsaeed, B. F. Yousif, and H. Ku, "The potential of using date palm fibres as reinforcement for polymeric composites," Materials and Design, vol. 43, pp. 177-184, Jan. 2013.

[17] E. R. Coats, F. J. Loge, M. P. Wolcott, K. Englund, and A. G. McDonald, "Production of natural fiber reinforced thermoplastic composites through the use of polyhydroxybutyrate-rich biomass," Bioresource Technology, vol. 99, pp. 2680-2686, May 2008.

[18] O. Faruk, A. K. Bledzki, H. P. Fink, and M. Sain, "Biocomposites reinforced with natural fibers: 2000-2010," Progress in Polymer Science, vol. 37, pp. 1552-1596, Nov. 2012.

[19] H. M. Akil, M. F. Omar, A. A. M. Mazuki, S. Safiee, Z. A. M. Ishak, and A. A. Bakar, "Kenaf fiber reinforced composites: A review," Materials and Design, vol. 32, pp. 4107-4121, Sep. 2011.

[20] A. Nishimura, H. Katayama, Y. Kawahara, and Y. Sugimura, "Characterization of kenaf phloem fibers in relation to stem growth," Industrial Crops and Products, vol. 37, pp. 547-552, May 2012.

[21] N. Nishimura, A. Izumi and K. Kuroda, "Structural characterization of kenaf lignin: Differences among kenaf varieties," Industrial Crops and Products, vol. 15, pp. 115-122, Mar. 2002.

[22] N. Saba, M. T. Paridah, M. Jawaid, K. Abdan, and N. A. Ibrahim, Manufacturing and Processing of Kenaf Fibre-Reinforced Epoxy Composites via Different Methods, ser. Manufacturing of Natural 
Fibre Reinforced Polymer Composites. Cham, Switzerland: Springer International Publishing, 2015.

[23] P. Lamp, "Advanced materials for future generations of automotive batteries: Potential and limits," in Proc. IMLB'16, 2016.

[24] N. Saba, M. T. Paridah, and M. Jawaid, "Mechanical properties of kenaf fibre reinforced polymer composite: A review," Construction and Building Materials, vol. 76, pp. 87-96, Feb. 2015.

[25] R. B. Yusoff, H. Takagi, and A. N. Nakagaito, "Tensile and flexural properties of polylactic acid-based hybrid green composites reinforced by kenaf, bamboo and coir fibers," Industrial Crops and Products, vol. 94, pp. 562-573, Dec. 2016.

[26] C. Baille, Green Composites, Florida, USA: CRC Press, 2004.
[27] I. M. Yassin, A. Zabidi, M. S. A. M. Ali, N. M. Tahir, H. A. Hassan, H. Z. Abidin, and Z. I. Rizman, "Binary particle swarm optimization structure selection of nonlinear autoregressive moving average with exogenous inputs (NARMAX) model of a flexible robot arm," International Journal on Advanced Science, Engineering and Information Technology, vol. 6, pp. 630-637, Oct. 2016.

[28] M. N. M. Nor, R. Jailani, N. M. Tahir, I. M. Yassin, Z. I. Rizman, and R. Hidayat, "EMG signals analysis of BF and RF muscles in autism spectrum disorder (ASD) during walking," International Journal on Advanced Science, Engineering and Information Technology, vol. 6, pp. 793-798, Oct. 2016. 